\title{
Contágio social em tribunais do júri
}

\author{
Marcela Zamboni* \\ Jairo Rocha de Faria**
}

\section{RESUMO}

Este trabalho foi realizado nos dois Tribunais do Júri de João Pessoa, entre os anos de 2015 e 2017. A partir da realização de entrevistas semiestruturadas com os juízes leigos, apresentamos uma reflexão acerca do funcionamento desses tribunais e do poder estabelecido entre os envolvidos na produção da sentença. Em seguida, utilizamos um modelo de contágio, amplamente utilizado na Sociologia Matemática e ajustado com os achados da pesquisa, a fim de explorar as dinâmicas do contágio social entre os jurados. Tanto a pesquisa qualitativa quanto os resultados da aplicação do modelo permitem concluir que os vícios de permanência do corpo de jurados, traduzidos na distinção entre juízes leigos neófitos e profissionais, podem comprometer significativamente a isenção do julgamento, em flagrante conflito com os princípios norteadores do tribunal do júri.

Palavras-chave: tribunal do júri; juízes leigos; contágio social.

* Professora e pesquisadora do Departamento de Ciências Sociais e do Programa de PósGraduação em Sociologia da UFPB, e coordenadora do GRAV (Grupo de Relações Afetivas e Violência). Endereço: Cidade Universitária, s/n - Castelo Branco III, João Pessoa - PB, 58051-900.

* * Professor do Departamento de Computação Científica e pesquisador do Programa de PósGraduação em Modelagem Matemática e Computacional da UFPB. 


\begin{abstract}
SOCIAL CONTAGION IN THE JURY COURTS

This work was carried out in the two Jury Courts of Joao Pessoa between the years 2015 and 2017. From semi-structured interviews with the lay judges, we present a reflection about the functioning of these courts and the power established among those involved in the production of the sentence. Next, we used a mathematical model of contagion, widely used in mathematical sociology and adjusted with the findings of the research, in order to explore the dynamics of social contagion among jurors. Both the qualitative research and the results of the application of the model allow us to conclude that the vices of permanence of the body of jurors, translated in the distinction between professional lay and neophyte ones can significantly compromise the exemption of the trial, in flagrant conflict with the guiding principles of the court of the jury.

Keywords: jury court; lay judges; social contagion.
\end{abstract}

\title{
Introdução
}

O homem que disse - eu prefiro ter sorte do que ser bom - viu profundamente a vida. As pessoas têm medo de enfrentar como grande parte dela é dependente da sorte. É assustador pensar que ela está fora de seu controle. Há momentos em um jogo quando a bola atinge o topo da rede, e, por uma fração de segundos, ela pode avançar ou retroceder. Com um pouco de sorte, ela vai para a frente e você ganha. Ou talvez não, e você perde (livre tradução do monólogo de Wood Allen, do filme Match point).

É certo que os princípios que fundamentam a existência dos tribunais no Brasil têm como alicerce o bem julgar. Por outro lado, pode-se afirmar que parte das decisões proferidas no setting de produção da pesquisa, que vem sendo realizada nos dois tribunais do júri da cidade de João Pessoa desde 2011, contam com uma dose significativa de sorte, não só pela natureza incerta da produção da sentença, mas também porque os vícios lá encontrados podem beneficiar ou não os réus, a depender das perspectivas morais dos julgadores. Tal como no monólogo supracitado, a vida dos réus parece estar em grande medida marcada por elementos imponderáveis de sorte ou azar.

Uma pequena amostra da assertiva acima será apresentada neste artigo com base nas entrevistas semiestruturadas realizadas com os juízes leigos 
dos dois tribunais do júri da cidade de João Pessoa (dados de 2015 a 2017), além de algumas observações do campo de pesquisa. Através da exploração de um modelo da Sociologia Matemática, pretendemos problematizar a propagação do contágio social entre os jurados.

De fato, um dos achados deste trabalho foi a constatação de que, no fórum criminal de João Pessoa, a rotatividade no alistamento do tribunal do júri estava sendo descumprida, permitindo que uma parte dos jurados fosse reconduzida para os anos seguintes. Outro achado importante da pesquisa foi que, embora a regra de incomunicabilidade seja observada durante as sessões de julgamento, ela parece obsoleta diante das novas possibilidades de comunicação da sociedade em rede (CASTELLS, 1999), principalmente através de aplicativos de mensagens instantâneas para smartphones, o que pode interferir na convicção pessoal do jurado.

Este contraste entre o regramento do ritual e os "atos do mundo diário" (DAMATTA, 1983 apud SCHRITZMEYER, 2012, p. 137) inspirou, dentre outras demandas, às seguintes questões: de que forma a falta de rotatividade na lista de jurados pode criar empreendedores morais (BECKER, 2008)? Como a rede de comunicação do conselho de sentença pode amplificar a influência dos empreendedores morais e contaminar a isenção do tribunal do júri?

Segundo Becker (2008), os empreendedores morais podem ser divididos em reformadores cruzados, ou criadores de regras, e impositores morais. No primeiro caso, a ação do grupo é considerada sagrada, sendo qualquer meio válido para extirpar aquilo que é tomado como o mal. Haveria, portanto, uma clara preocupação com o conteúdo das regras. Já os impositores estariam interessados, em princípio, com a manutenção da regra, já que dela dependeria a sua posição profissional ou modo de vida.

Considerando o caráter variável do julgamento e a liberdade de interpretação dos operadores jurídicos nos tribunais do júri, pode-se atribuir a tais profissionais tanto o lugar de reformadores cruzados quanto de impositores morais. Aos juízes leigos, restaria apenas a segunda opção, já que lhes cabe a decisão do julgamento, mesmo diante das influências e dificuldades de interpretação. Deve-se enfatizar a preocupação de parte deles com o reconhecimento do papel desempenhado tanto pelos seus pares quanto pelos operadores jurídicos e ainda com as possibilidades hermenêuticas que são incorporadas na produção da sentença. 
Através de um modelo da Sociologia Matemática (COLEMAN, 1964), realizamos simulações para melhor compreender como os vícios observados podem propagar valores morais no tribunal do júri. Mais especificamente, adotamos de modo heurístico (WILSON, 1999, p. 573) um modelo epidemiológico que tem sido utilizado em diversas áreas da sociologia, como na difusão de rumores (DALEY; GANI, 2005), na propagação de violência (PATTEN; ARBOLEDA-FLOREZ, 2004), abuso de drogas e tráfico, suicídio, associação de gangues, violência afetivo-conjugal, agressão sexual, bullying (SAMPSON et al., 1997), dentre outras.

A tese que se defende, portanto, é que alguns fenômenos sociais são transmitidos de um indivíduo para outro por um contágio social, o que na sociologia de Tarde (2000) foi denominado de contágio imitativo, e que esta transmissão se dá de modo análogo a um contágio epidêmico.

Devemos ressaltar que a postura adotada em nossa análise sociológica, amparada também por um modelo matemático, corrobora com a apresentada por Wilson (1999), que afirma:

(...) podemos e devemos fazer uso de modelos matemáticos para descobrir relações em nossos dados e esclarecer nossas ideias a respeito de como uma coisa se liga a outra num caso particular. Mas não podemos ver na matemática o idioma próprio para a formulação de conceitos e proposições fundamentais que ensejem uma ciência natural de sociedade (p. 575).

Neste sentido, o modelo de contágio pode ser utilizado como instrumento adequado na concepção de princípios e postulados acerca do tribunal do júri. Mais especificamente, utilizamos o modelo para investigar como a inobservância das normas jurídicas pode afetar a propagação de valores.

Este trabalho está organizado em quatro seções. A primeira trata da discussão teórico-metodológica que norteou a pesquisa. Em seguida, introduzimos os conceitos de juízes leigos neófitos e profissionais que evidenciam os já mencionados vícios. O distanciamento entre os mundos social e jurídico é discutido na terceira seção. O modelo matemático para a análise do contágio social nos tribunais do júri é explorado na quarta seção. Finalmente, apresentamos nossas considerações finais. 


\section{Discussão teórico-metodológica}

A motivação inicial do projeto de pesquisa que resultou neste trabalho foi a realização de um levantamento acerca da percepção dos operadores jurídicos em casos de homicídio afetivo-conjugal, que teve início em 2011 nos mesmos tribunais do júri deste artigo. A partir da dissonância entre as normas legais e as práticas procedimentais observadas no setting de julgamento, nos propomos a investigar o funcionamento dos tribunais do júri e como estas divergências poderiam influenciar nas suas decisões. Neste sentido, os momentos que antecederam os julgamentos e os bastidores desses rituais de interação observados desde o início da pesquisa foram fundamentais à problematização apresentada aqui e corroboraram com os resultados das entrevistas que serão apresentados.

Lima (1999) afirmaria que houve uma incorporação voluntária ou involuntária da pesquisa. A fachada silenciosa e contida dos juízes leigos durante quase todo o ritual dos julgamentos e observada ao longo da pesquisa só pode ser mais bem compreendida dentro de um contexto de análise de rituais do júri mais amplo. Os achados da pesquisa relativos ao ritual de interação e à análise situacional podem ser encontrados em publicações anteriores (ZAMBONI; OLIVEIRA, 2015; 2016).

Como principal instrumento de análise, apresentaremos os resultados das cinquenta entrevistas semiestruturadas que foram realizadas com juízes leigos, concedidas tanto nos tribunais do júri quanto em outros locais de preferência dos pesquisados (local de trabalho ou residência). Constatamos que, longe dos olhares e dos ouvidos da mencionada instituição jurídica, os temas abordados foram tratados com mais descontração.

A partir da pesquisa de campo que pavimentou este trabalho, a necessidade de investigar o cumprimento das regras que dão sustentação ao estatuto do tribunal do júri tornou-se imperativa. Em especial, buscamos identificar as falhas do bem julgar, a exemplo do tempo de atuação do juiz leigo, do tipo de relação estabelecida entre os juízes leigos e desses com os operadores jurídicos.

Uma questão crucial para a exploração dos primeiros resultados de nossa pesquisa foi como estas falhas favorecem o surgimento de impositores morais e contribuem para a disseminação de valores - neste trabalho, denominados de contágio social -, interferindo nas decisões do conselho de sentença. 
A fim de analisar, sob a ótica da Sociologia Matemática, os achados das entrevistas relacionados aos vícios encontrados no tribunal do júri, dois modelos bastante evidenciados na literatura se apresentaram, inicialmente, como alternativas viáveis para este estudo: o primeiro, através da análise de redes sociais, e o segundo, através de modelos epidemiológicos.

Embora o primeiro modelo venha desempenhando nos últimos anos um papel de relevância na Sociologia Matemática, a construção da rede social de um tribunal de justiça não é viável pela falta de registros disponíveis, ao contrário de outras redes sociais como a rede de coautoria de artigos científicos e a rede de atores de filmes, que desempenham importante papel na análise e modelagem de redes sociais (BARABÁSI, 2002). Além do mais, tais relações de amizade não são desejáveis entre aqueles que compõem o tribunal do júri.

Por outro lado, Coleman (1964, p. 46) afirma que, embora alguns modelos tenham sido desenvolvidos para o estudo da propagação de doenças contagiosas, eles podem ser aplicáveis aos fenômenos socialmente contagiosos. O autor ainda previu que seria apenas uma questão de tempo até que fenômenos sociais, como o crescimento de manias e modas, propagação de notícias, aumento e queda de demagogos, entre outras situações, estivessem sujeitos à análise através desses modelos de difusão, que representam um tipo de teoria sintética nas ciências sociais.

Wilson (1999), por sua vez, ilustra a tese heurística através do uso de um modelo de "difusão de mensagens boca a boca”, onde conclui:

Sem dúvida, essa historieta foi contada como advertência contra certo tipo de ingenuidade na elaboração de experiências (...). O ponto mais importante a ser notado é que, estabelecidas as regras (...), o modelo forneceu uma descrição empiricamente adequada que podia ser útil para diversas finalidades. Além de aplicações práticas, como estimar a quantidade de tempo necessária para se espalhar um determinado boato, o modelo podia ser usado para entender um pouco as implicações das regras que presidiam às regularidades por ele representadas (p. 574).

Por conseguinte, neste trabalho, adotamos o já amplamente estudado modelo de Kermack-McKendrick (KERMACK; MCKENDRICK, 1927) para sustentar nossa análise sociológica sobre a propagação de vícios nos tribunais do júri. 
Antes, no entanto, devemos lembrar quem são os atores que compõem o cenário analisado e quais são as regras do jogo.

\section{Juízes leigos: dos neófitos aos profissionais}

No rito processual, em momento anterior ao envio do processo penal ao tribunal do júri, o promotor de justiça denuncia a autor do crime, com base no inquérito policial que é encaminhado ao Ministério Público. A denúncia é então analisada pelo juiz de direito, que cita e interroga o acusado, além de ouvir as testemunhas de acusação e de defesa. Ao final desta fase, o promotor público e o advogado de defesa encaminham as suas alegações finais para que o juiz possa proferir a pronúncia, impronúncia, desclassificação ou absolvição $^{1}$ do réu. Em caso de pronúncia, encaminha-se o processo criminal ao Tribunal do Júri, órgão de justiça responsável pelos julgamentos de todos os crimes dolosos contra a vida, na sua forma tentada ou consumada: o homicídio, o infanticídio, o aborto e ainda a instigação, o induzimento ou o auxílio ao suicídio.

O colegiado de cada tribunal do júri é formado por um juiz-presidente, magistrado do poder judiciário; por sete juízes leigos ou representantes da sociedade civil; pelo promotor público e pela defensoria pública ou advogado particular. Depois da disputa que se estabelece entre as teses de defesa e de acusação, cabe ao conselho de sentença (formado pelos juízes leigos), condenar ou absolver o réu. Na primeira hipótese, o juiz togado ${ }^{2}$ define a dosimetria da pena.

Os jurados são também conhecidos como juízes leigos, júri, júri popular, tribunal do povo, colegiado popular ou tribunal popular (LOREA, 2003, p. 07). Esses representantes diretos da sociedade civil são escolhidos segundo o critério de idoneidade. No entanto, há uma controvérsia no meio jurídico que divide as posições entre aqueles que pretendem ampliar a participação dos juízes leigos dentre os representantes de diversos setores da sociedade

1 A pronúncia do juiz significa o reconhecimento de indícios de autoria e provas materiais do crime doloso contra a vida. Neste caso, o processo segue as regras definidas pelo Tribunal do Júri. A impronúncia ocorre quando o juiz duvida da existência do crime ou da participação do réu, sendo considerada um tipo de sentença. Já a absolvição sumária pode ocorrer em dois casos: quando há comprovação da inexistência do fato ou quando o crime não é tomado como infração penal, a exemplo da legítima defesa. Assim como a impronúncia, a absolvição sumária é um tipo de sentença onde se avalia o mérito da ação.

2 Bacharel em Direito e servidor público do Estado. 
e os que defendem o aspecto intelectivo como critério de seleção (LOREA, 2003, p. 35).

Nos casos de crimes dolosos contra a vida, não os é outorgado conhecimento técnico-científico na área jurídica. Mais do que isso, pretende-se dar lugar aos mais diversos representantes da sociedade civil, capazes de julgar em que medida a ação delituosa fere as regras sociais e morais ou pode receber a benesse do perdão. Deve-se destacar, portanto, a particularidade e liberdade de tomada de decisão deste corpo de jurados.

Cabe lembrar que, diferentemente dos demais tribunais de justiça, o júri tem o poder de absolver um réu culpado, ou seja, o seu veredito é soberano. Como destaca Nucci (2014),

o tribunal, ao dar provimento ao apelo, embora não possa invadir o mérito e apenas determine a realização de novo julgamento pelo Tribunal do Júri (atuando outro conselho de sentença), está, na essência, revendo a decisão e valorando, sob seu ponto de vista, a prova existente. Tal medida é incabível e inconstitucional. (pp. 461-462).

A importância da existência do júri foi enfatizada no trabalho de Sestini (1979), através do relato de um advogado de defesa:

O júri existe no Brasil e em outros países, para fazer aquilo que o juiz togado não tem condições de fazer pela expressão fria da lei. Os jurados não julgam crimes, mas criminosos, o que os diferencia dos juízes togados e do julgador profissional. (p. 131).

Na medida em que nos afastamos da "expressão fria da lei” mencionada acima, criamos um espaço onde o exercício de se colocar no lugar do outro se faz necessário, permitindo inclusive que a empatia e o perdão deem espaço à condenação até mesmo de réus confessos, eximindo-os de qualquer sanção legal. Mas, como será explicitado no texto, a importância do júri destacada na citação acima deu lugar a um sentido diverso, criado a partir da distinção entre juízes leigos neófitos e profissionais. A ideia de que os sentimentos expressos de forma espontânea costumam ser tomados como mais elegantes, segundo o padrão formal do intercâmbio ritualístico e em oposição aqueles elaborados de forma consciente (GOFFMAN, 2011, p. 30), é diametralmente oposta à dos juízes leigos profissionais. 
A necessidade de um quadro mais amplo do modus operandi dos tribunais do júri, independente dos tipos de crime ${ }^{3}$ e dos atores envolvidos, tem sido apontada também em outras pesquisas (SESTINI, 1979; CORRÊA, 1983; ADORNO, 1994; JUNQUEIRA, 1996; IZUMINO, 1998; LIMA, 1999; SADEK, 2001; MISSE; VARGAS, 2007; RATTON; CIRENO, 2007; RIBEIRO, 2009; DEBERT et al., 2008 etc.). Devem-se considerar as regras de funcionamento explícitas e/ou ocultas em cada tribunal e que as possíveis variações entre as normas procedimentais e o dia a dia do júri dependem em grande medida daqueles que detêm o poder de decisão.

Um dos problemas do descumprimento das regras legais nos tribunais do júri refere-se ao princípio de rotatividade e tempo de atuação dos juízes leigos. Segundo o Código de Processo Penal (CPP) em seu artigo 426, § 4º o jurado que tiver participado do "Conselho de Sentença nos 12 (doze) meses que antecederem à publicação da lista geral fica dela excluído” (BRASIL, 1941).

Neste trabalho, consideramos que o princípio de igualdade no âmbito da justiça não pressupõe uma divisão aritmética de tudo entre todos, devendo-se considerar a magnitude relativa entre aqueles que realizam a distribuição, a partir de um princípio de equivalência. A manutenção da ordem ancora-se em uma ilusão, considerando a distância estabelecida entre as reivindicações ideais dos atores, a realidade oculta dos interesses e a necessidade de coação (BOLTANSKI, 2000, pp. 32-39).

Podemos utilizar aqui a imagem de uma estrutura piramidal da justiça brasileira, marcada pela separação e hierarquia que revela a sua forma desigual, apesar de complementar, tal como aquela apresentada por Lima (1999):

(...) Quem está no topo, no vértice, é o único que tudo vê, cuja perspectiva é a verdadeira, pois os demais elementos têm apenas visões parciais do conjunto, tanto mais distorcidas quanto mais próximos à base se encontrem. (p. 25).

Em pesquisa realizada nos mesmos tribunais do júri, Zamboni e Oliveira (2015, p. 47) questionaram o amplo apoio a tais instituições por parte dos operadores jurídicos, que destacaram a possibilidade de condenação dos acusados, mesmo diante de provas irrefutavelmente frágeis. Os alvos pre-

3 Deve-se enfatizar que não se trata de afirmar a inexistência das especificidades nos crimes que são julgados nos tribunais do júri. 
ferenciais de tais condenações já foram objeto de diversos estudos no Brasil (FAUSTO, 1984; ADORNO, 1994; LIMA, 1999; MISSE, 2010, etc.), havendo um claro recorte de classe, cor, estilo de vida etc.

Seus crimes os diferenciam de todos os outros autores de crime, não são apenas criminosos; são ‘marginais', ‘violentos', 'bandidos'. (MISSE, 2010, p. 18).

Apesar de constatarmos sinais de movimentação na lista anual de jurados a partir de 2016, em contrapartida às informações coletadas em 20154, a figura dos "jurados vitalícios” ainda se faz presente nos dois tribunais do júri de João Pessoa. Dentre os casos registrados, podemos citar alguns emblemáticos: a. vinte anos de júri, com seis anos de afastamento; b. oito anos, com dois anos de intervalo; c. dezessete anos ininterruptos. Nossos achados corroboram com estudos que têm demonstrado uma tendência à longevidade ${ }^{5}$ do corpo de jurados e ao descumprimento dos critérios de rotatividade ou substituição da lista desses, entre um ano e outro (LOREA, 2003; BATITUCCI; CRUZ, 2006; FACHINETTO, 2012).

A fim de evidenciar o tempo de atuação dos juízes leigos, dividiremos esse grupo em duas categorias: neófitos e profissionais (Figura 01).

Figura 1 - Juízes leigos neófitos e Juízes leigos profissionais.

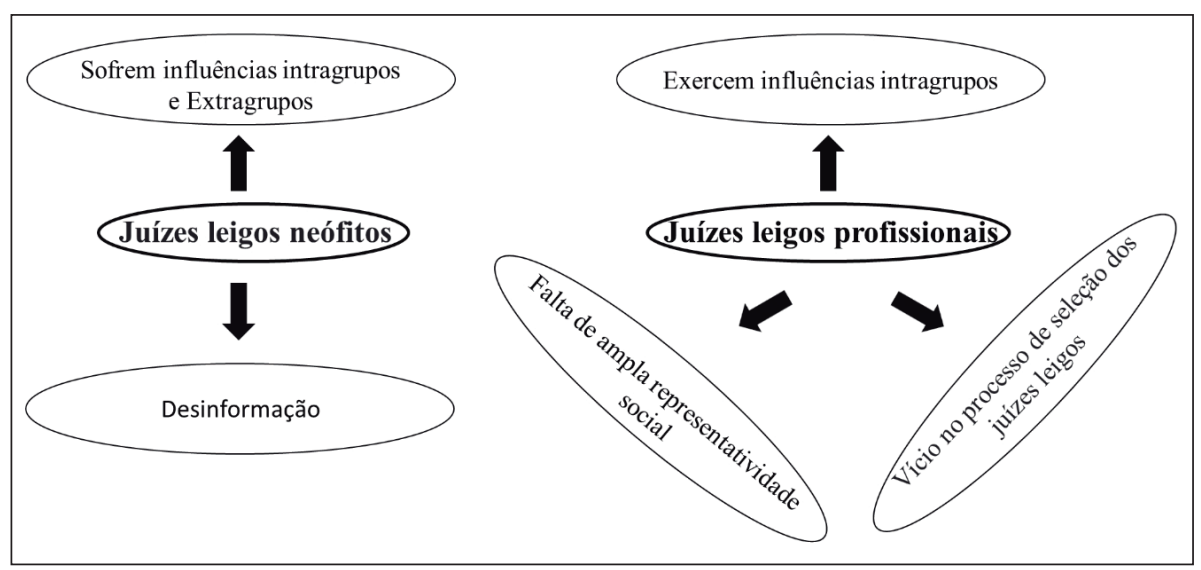

4 Não sabemos se tal mudança está relacionada com a pesquisa, já que essa pode ser tomada também como uma forma de controle das práticas jurídicas.

5 A fiscalização de tal lista é atribuição do Ministério Público (LOREA, 2003, p.43). 
Um dos problemas decorrentes da violação ao CPP em relação ao tempo de permanência dos jurados refere-se às relações de proximidade e familiaridade observadas durante a pesquisa não só entre o grupo dos juízes leigos, mas também desses com os operadores jurídicos. Nesta lógica de funcionamento, os jurados profissionais e os operadores jurídicos lançam mão da máscara (em termos goffmanianos) de "cicerones" dos jurados neófitos ou "aprendizes", apresentando a eles o mundo jurídico e influenciando os seus olhares.

Se a preocupação com o princípio de rotatividade, a fim de evitar a permanência dos jurados profissionais, é importante, deve-se também destacar aqui a falta de informação e preparo de alguns recém-chegados. Mesmo já tendo atuado como jurada, uma das entrevistadas desconhecia a possibilidade de fazer perguntas ou solicitar esclarecimentos durante o julgamento, a fim de dirimir dúvidas acerca do caso:

Entrevistadora: "Podemos observar em pesquisa anterior realizada no fórum que em geral, os juízes leigos não costumam fazer perguntas durante o julgamento. Por que?"

Entrevistada: "Acho que é porque não é permitido, né?"

Entrevistadora: "Não. É permitido".

Entrevistada: "E é?"

Entrevistadora: "É permitido, a senhora sabia?"

Entrevistada: "Não" (Entrevista 03).

Não se pode desconsiderar também que a falta de rodízio caracteriza uma violação ao princípio mais geral da existência do corpo de jurados, que é a efetiva participação da sociedade, através de seus diversos representantes. Além disso, a familiaridade entre os envolvidos é danosa porque a seleção dos atores que julgam pode ser constituída de informações prévias sobre os julgadores.

Tanto o contato entre as partes envolvidas no julgamento quanto as teses jurídicas apresentadas podem ser tomados como aspectos relevantes para o bem julgar. Por outro lado, particularmente quando há certa repetição dos representantes da defesa e da acusação, podem haver preferências ou recusas ${ }^{6}$ por ambas às partes. Além da perda de naturalidade, haveria também a quebra da

6 Pode haver até três recusas para cada parte (defesa ou acusação), sem qualquer justificativa para tais substituições. 
imparcialidade plena do jurado, como representante da sociedade que julga um caso inédito (NUCCI, 2014, p. 174). Neste sentido, deve-se analisar a agência do agente e a agência da estrutura como dispositivos que podem ser acionados segundo as gramáticas situacionais apropriadas e necessárias (WERNECK, 2013, p. 707). Em determinadas situações, pode-se chegar a acordos justificáveis e universalizáveis capazes de sustentar a denúncia como simples relação de forças tomadas como relações de justiça (BOLTANSKI, 2000, p. 69), a exemplo da preferência de jurados homens, por parte dos defensores públicos, e do gênero oposto, por parte da promotoria, quando se julga um caso de feminicídio ${ }^{7}$.

“O julgamento não pode ocorrer por falta de quórum” foi o que declarou uma das entrevistadas quando do encontro com nove juízes leigos fora dos tribunais do júri, referindo-se ao Art. 463 do CPP que menciona a necessidade da presença de pelo menos quinze jurados, para que o processo de julgamento possa ser iniciado. A situação pode ser tomada como

(...) um setting ao mesmo tempo de acontecimento, da experiência, da própria vida social em sua fenomenologia, e da moral, do aparato de verificação pelos actantes da efetividade - em termos do bem - do que acontece. (WERNECK, 2013, p.712).

Uma das definições acerca da diferença entre a sociologia da moral ${ }^{8}$ e a sociologia moral é a de que, no primeiro caso, poder-se-ia considerar a moralidade como variável dependente e, no segundo, como variável independente (VANDENBERGHE, 2015, p.67). Tal distinção não parece apropriada quando se reflexiona a relação de interdependência entre a moral dos responsáveis pelo julgamento e o mundo social. Assim, não se pode considerar, por exemplo, que o tempo de permanência e o perfil dos juízes leigos devam ser tomados como variáveis dependentes que explicariam, de forma irrestrita, as falhas do "bem julgar". Por outro lado, deve-se refletir acerca da relação que se impõe entre os descumprimentos legais e a produção da sentença.

7 Segundo os operadores jurídicos entrevistados nos mesmos tribunais do júri (ZAMBONI; OLIVEIRA, 2016), as mulheres costumam ser mais sensíveis aos casos de feminicídio, julgando os homens com mais severidade.

8 Tal como no trabalho de Pharo (2015, p. 199), há de se distinguir neste artigo os termos "ética" e "moral", sendo o primeiro mais adequado para se referir as condutas da vida prática e o segundo, um conjunto de regras ou doutrina social. Quando se trata da sociologia moral, deve-se expandir o termo moral, a partir da definição entre o que é bom ou mau, proibido ou aceito etc. 


\section{Do saber leigo ao técnico}

Estudos na área das Ciências Sociais jurídicas (SESTINI, 1979; CORRÊA, 1983; ADORNO, 1994; SADEK, 2001; SCHRITZMEYER, 2007; BLAY, 2008; FACHINETTO, 2012; ZAMBONI; OLIVEIRA, 2016; entre outros), têm reiterado o uso excessivo da linguagem técnica e investimento performático, por parte dos operadores jurídicos, a fim de convencer os jurados de suas teses. O resultado de tal atuação costuma variar entre o encantamento, o aborrecimento, a impotência ou o constrangimento daqueles que não compreendem os códigos do ritual de julgamento, mesmo quando já ocupam o banco decisório e não se eximem de proferir sentença. Tais sentimentos foram também observados em nossa pesquisa. Sobre o processo de admiração dos juízes leigos, um deles mencionou a postura do juiz:

De confiança porque ele falava que o jurado era em primeiro lugar. Ele chegava, dava bom dia, ia, dava boa noite. (...) muito simpático ele. E a gente, quando olhava para ele, fazia: nossa, ele vai ser chato. Na verdade, ele não era chato. Ele era, ele era, eu achei uma coisa muito interessante, amistoso. (...) teve uma vez que um réu estava lá e não tinha tomado café. O juiz pediu para um oficial comprar um lanche e dar para ele comer e o juiz que pagou. Achei muito interessante. (Entrevista 6).

Durante os rituais dos julgamentos observados, o frequente silêncio dos juízes leigos não parecia apenas indicar que os casos em pauta eram apresentados sem que restassem dúvidas e desejo de indagações. Além da preocupação desses atores com a exposição de sua própria imagem, em casos amplamente divulgados pela imprensa, e do receio de alguma retaliação por parte dos réus ou de familiares, ficou claro que há um desconforto entre o corpo de jurados relativo à atuação dos operadores jurídicos. A possível repreensão do juiz e o temor em ser constantemente citado pela defesa e/ou acusação, após pedido de esclarecimento das teses apresentadas, foram também destacados como possíveis causas do emudecimento, ultrapassando, em grande medida, as diferenças intelectivas e profissionais que existiam entre eles. Segundo o relato de uma das juízas leigas entrevistadas:

(...) a maioria são pessoas leigas que não têm muito conhecimento, a gente procura se ater ao que a defesa e ao que a acusação falam duran- 
te o julgamento. Ao que mais ou menos a gente entende, vamos dizer assim, superficialmente. Aí não há, o juiz sempre pergunta: alguma dúvida? Algum questionamento? Geralmente é algum receio de fazer alguma pergunta inadequada, essa é a verdade. (Entrevista 08).

Apesar do relato acima, os juízes leigos destacaram a importância da experiência de vida como contraponto ao conhecimento técnico. Entre um e outro, a primeira deveria prevalecer. Tal resposta corrobora com a própria razão de ser do conselho de sentença. Se o conhecimento técnico fosse determinante, os juízes leigos não teriam assento decisório nos tribunais do júri. Por outro lado, a utilização de termos técnicos foi mencionada como um obstáculo à compreensão mais ampla dos casos julgados e a consequente manipulação do corpo jurídico, resultando, em alguns casos, na produção de sentença não pretendida por parte dos jurados. Mesmo diante das falhas elencadas, os jurados declararam que são a favor da continuidade dos tribunais do júri, porque com tal participação popular seria possível garantir certa justiça social.

Para Schritzmeyer (2007, pp. 111-112), os argumentos contrários ou favoráveis à existência do tribunal do júri são diversos. Aos favoráveis, por exemplo, costuma-se alegar que o esforço despendido pelos operadores jurídicos em utilizar linguagem acessível aos juízes leigos resultaria em maior publicidade e "administração da justiça”. Por outro lado, destaca-se a necessidade de rigor técnico, considerando a natureza complexa dos crimes.

Segundo os juízes leigos, o vocabulário utilizado por alguns operadores jurídicos marca o distanciamento entre o mundo social e o jurídico. A linguagem excessivamente técnica parece ofuscar a objetividade dos casos, podendo confundir e enganar o corpo de jurados. As razões que levam os operadores jurídicos a elaborarem questões de difícil compreensão ou apresentarem o caso utilizando-se de linguagem rebuscada, considerando o nível educacional médio do cidadão brasileiro, não se restringem às insensibilidades dos agentes. A tentativa de influenciar o corpo de jurados foi percebida por alguns entrevistados. Segundo o relato de um deles:

Assim, num país que o povo sabe o que é um sim, o que é um não, sabe o que é uma pergunta, que você pode inverter a pergunta ao contrário. O brasileiro se você inverter a pergunta, ele erra. Se você perguntar de um jeito ele sabe, mas se você trocar as palavras ele vai responder errado. Por isso que eu digo, eu acho temerário. (Entrevista 01). 
A relação estabelecida entre os operadores jurídicos e os juízes leigos, apesar de amistosa, parece também ser marcada por interesses de sedução, convencimento ou intimidação. Segundo o relato dos juízes leigos, esta seria uma outra estratégia:

Assim, é boa, mas eu acho que ela não é verdadeira. É educada, cortês. Existe todo o elogio, a pompa e a circunstância, porque eles estão buscando o convencimento dos jurados. Você observa que a técnica deles, tanto da acusação quanto da defesa, é: fez o sorteio e eles anotam o nome dos jurados - Já presenciei isso algumas vezes - e quando eles vão fazer as explanações eles nomeiam com quem estão falando. Eu não sei se meio para intimidar, ou se para fazer com que aquele jurado se sinta importante no processo, porque também é uma alegação constante de que tudo ali vai acontecer em função do julgamento do Conselho de Sentença, absolver ou condenar o réu é uma decisão que vai ser apenas lida pelo juiz, mas que vai ser determinada pelo Conselho. Então assim, a reiteração constante dessa responsabilidade que o júri tem é feita tanto de um lado, quanto do outro. Aí quando eu digo assim: "ela é cortês, é educada, mas eu não sei se é verdadeira" é porque eles estão nesse intuito do convencimento, entendeu? E eles vão lançar mão de todos os artifícios que eles tiverem: do chegar perto, falar olhando no olho, do chamar pelo nome, chamar para o processo, para participar, entender o que se passa. (Entrevista 10).

...eu percebo assim na parte bem mais da defesa, eles procuram antes do julgamento conversar, criar uma empatia com a gente. Eu percebo que o Ministério Público não tem essa preocupação, o juiz não tem, não é que eles não nos tratem bem, pelo contrário. Mas eu percebo que a defesa ${ }^{9}$ se preocupa sim, vai se mostrar bem disponível e para mim é óbvio: eles querem criar empatia. Eu chego lá e digo: 'oh, chegar lá, a defensoria vai dizer isso contigo', e é óbvio que eles querem seu voto, é só isso. (Entrevista 01).

Para outros, a relação amistosa não era apenas movida pelo interesse ou estratégia profissional. Em alguns casos, o vínculo estabelecido entre os juízes leigos e os operadores jurídicos era também de amizade:

9 Em pesquisa realizada nos mesmos tribunais do júri (ZAMBONI; OLIVEIRA, 2016), os defensores públicos se queixaram do contato prévio entre os promotores públicos e os juízes leigos, destacando certa desvantagem entre defesa e acusação. 
Entrevistada: "A gente teve uma relação muito boa. Principalmente porque estávamos lá durante um mês, todo dia. E geralmente tinha, são, se não me engano, só foram dois promotores. E defensores públicos, se não me engano, três. Então queira ou não queira, a gente conversava antes das sessões. Não sobre os casos, mas conversava sobre algum fato. Então tinha uma comunicação bastante dinâmica entre a gente."

Entrevistadora: "Chegava a ser uma relação afetuosa? Ou não? Mais profissional mesmo?"

Entrevistada: "Sim, algumas amizades. Quando a gente terminou, a gente foi fazer um rodízio com o pessoal, chamamos alguns promotores."

Entrevistadora: "E eles foram?"

Entrevistada: "Foram. Então teve a relação profissional, quando começava o julgamento, era totalmente profissional. Mas fora o julgamento, normal” (Entrevista 10).

Olha, vou tirar pela minha experiência, eu não tive muito esse contato, não. Mas a equipe que estava comigo já tinha já conhecimento, já conhecia, já vinha de outras, outras sessões antigas, então já tinha bastante afinidade, amizade, né? Então, assim, da minha parte, como eu disse a você, eu me senti um peixe fora d'água. (Entrevista 04).

Sestini (1979, p. 163) afirmou que, ao final dos julgamentos, os operadores jurídicos costumavam ser conhecedores dos votos de cada jurado. Os resultados de nossa pesquisa apontam para a mesma direção.

Não foi só a estreita proximidade entre os juízes leigos e os operadores jurídicos que nos fez refletir acerca das regras do tribunal do júri. No decorrer das entrevistas, nos deparamos com a existência de um grupo de WhatsApp (aplicativo para a troca de mensagens via smartphones) formado apenas por juízes leigos. A sintonia de posição relativa às questões trazidas pelo roteiro de entrevista não nos deixou dúvidas do interesse do grupo nos casos que são julgados nos tribunais do júri, além da intimidade presente naquele espaço virtual.

Com a realização da entrevista com mais de um membro do grupo doWhatsApp, algumas semelhanças nas respostas foram observadas, tal como a repetição da sentença: “é um fato que está sendo julgado ali”, frequentemen- 
te utilizada pelos operadores jurídicos. Quando indagados acerca do recorte de classe nos julgamentos, mais de um entrevistado lembrou o caso de duas meninas que foram brutalmente assassinadas sem que houvesse nenhum tipo de repercussão midiática, já que elas pertenciam às camadas sociais menos favorecidas.

O envolvimento entre os juízes leigos e deles com os operadores jurídicos surpreende. As opiniões relativas à regra da incomunicabilidade são divididas, variando entre os que acreditam nela, tendo em conta o desnível de conhecimento que há entre um jurado e outro, e a importância da tomada de decisão conjunta, como forma de produzir um julgamento mais justo.

Interessante ressaltar que os entrevistados destacaram que, na interação entre os sete jurados selecionados e os operadores jurídicos, nos intervalos dos julgamentos, não se falava do processo julgado, mas de assuntos diversos, e que existia uma efetiva fiscalização, a fim de evitar que o caso fosse mencionado, tal como se pode observar no relato:

Você vai para o lanche, você vai fazer o lanche e vai fazer a refeição, está certo, está lá, tem o representante da justiça lá para você não comunicar. Você vai para o WC, está certo, só entra de um em um. (Entrevista 09).

Ao que tudo indica, a expressa determinação referente à incomunicabilidade dos jurados ${ }^{10}$ vem sendo cumprida. Apesar disso, a comunicação e proximidade anteriores aos julgamentos não foram mencionadas, como se a fiscalização que ocorre no dia do julgamento fosse suficiente para conter os vínculos e as influências observadas ${ }^{11}$.

A maioria dos jurados entrevistados concordou com a necessidade da regra da incomunicabilidade entre eles, a fim de evitar que o julgamento fosse modificado, principalmente em decorrência da experiência dos mais antigos.

Se você pega alguém inteligente que está lá, que consegue a confiança, ele pode manipular o júri da forma que ele queira. Eu acho perigoso pelo nosso nível cultural e intelectual. (Entrevista 01).

10 Para mais detalhes, consultar o $\$ 1^{\circ}$ do artigo 466 do CPP.

11 A incomunicabilidade dos jurados é tema bastante controverso. Os que são contrários ao voto individual de cada jurado alegam que tal procedimento fere os princípios da democracia (Consultar NUCCI, 2014). 
A produção da sentença pode ser comprometida pela preocupação dos juízes leigos em atender às expectativas do corpo técnico ou pelas ingerências dos jurados profissionais sobre os neófitos. Como a influência dos operadores jurídicos sobre os juízes leigos pode ocorrer mesmo que o critério de rotatividade seja respeitado e não há mecanismos legais que evitem certos tipos de influência desse grupo, optamos por analisar aqui apenas o contágio entre os juízes leigos, já que esse ocorre em flagrante descumprimento legal e tende a interferir no resultado do julgamento. Tal análise será realizada na próxima seção, à luz da Sociologia Matemática.

\section{Contágio de valores entre os juízes leigos}

Para auxiliar na compreensão do contágio social no tribunal do júri, adotamos o clássico modelo de Kermack-McKendrick e consideramos o corpo de jurados formado por três categorias mutuamente excludentes: o empreendedor moral (jurado profissional), o suscetível (neófitos influenciáveis) e o refratário (neófitos resistentes às influências). O modelo matemático é representado pelo seguinte conjunto de equações:

$$
\begin{gathered}
x_{n+1}=(1-p)^{y_{n}} x_{n} \\
y_{n+1}=\left(1-e^{-a y_{n}}\right)^{y_{n}} x_{n}+b y_{n} \\
z_{n+1}=z_{n}+(1-b) y_{n}
\end{gathered}
$$

Onde $p$ é a probabilidade de influência, $a=-\log (1-p)$, $b$ é a proporção de permanência dos influenciados e $x_{n}, y_{n}$ e $z_{n}$ representam os números de jurados suscetíveis, empreendedores morais e refratários no estágio de tempo $n$, respectivamente.

Inicialmente, o conjunto de empreendedores morais é formado apenas pelos jurados profissionais. Os demais membros do conselho de sentença são classificados como refratários ou suscetíveis. Embora a população de refratários permaneça constante ao longo dos doze meses de validade do alistamento, a cada sorteio existe uma probabilidade de os empreendedores morais influenciarem parte dos jurados suscetíveis, o que os transformaria em novos impositores morais.

Nas simulações, consideramos um conjunto de setecentos alistados, sendo sorteados sete jurados por julgamento semanal, como preconiza o CPP 
para uma cidade do porte de João Pessoa, onde realizamos nosso estudo de campo. Também consideramos a proporção de 20\% de juízes leigos profissionais, em consonância com os dados coletados na pesquisa de campo.

Analisamos dois casos extremos:

a) quando a interação entre os empreendedores morais e jurados suscetíveis se dá apenas no grupo de sete jurados sorteados para participar de um mesmo tribunal do júri semanal. Neste caso, a população de empreendedores morais cresce de acordo com o valor esperado (VE) de contaminação por sessão semanal;

b) a exemplo do que acontece com a propagação de doenças infectocontagiosas, após um juiz neófito ser sorteado, ele passa a interagir com o restante da população corroborando com os achados da pesquisa que identificou a existência de uma rede virtual de comunicação de juízes leigos.

Finalmente, por conta da difícil estatística sobre as proporções de jurados refratários e suscetíveis, realizamos simulações considerando taxas de 25\%, 50\% e 75\% de suscetíveis dentre os neófitos, como representado na Figura 02.

Figura 2 - Simulações computando-se os Valores Esperados (VE) do caso "a" e utilizando o modelo de Kermack-McKendrick (K-M) - caso "b", considerando-se as proporções de suscetíveis como 25\%, $50 \%$ e 75\% dentre os jurados neófitos.

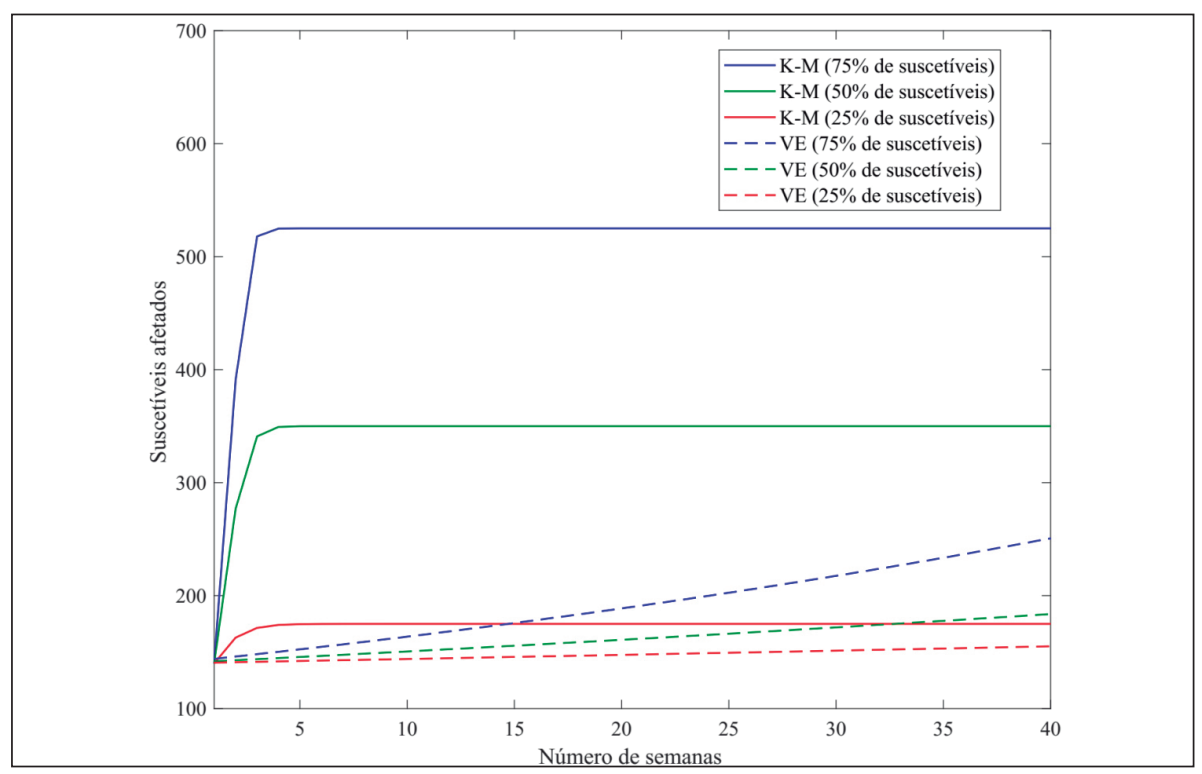


Os resultados da simulação demonstram que, além da inobservância da regra da rotatividade na lista de jurados, a existência de uma rede de comunicação entre os juízes leigos desempenha um papel significativo no contágio social no tribunal do júri. Assim, levando-se em conta a transcendência do tempo e do espaço na comunicação da nova sociedade em rede, torna-se imperioso obstar o surgimento de empreendedores morais.

Com efeito, observando-se o caso b, em que a probabilidade de interação entre os juízes leigos profissionais e neófitos é baixa (utilizamos $p=0.75 \%$ ), após cerca de cinco semanas, existe uma alta probabilidade de que todos os suscetíveis tenham sido influenciados.

Observamos ainda, através do caso a, que a simples existência de empreendedores morais ganha importância à medida que se aumenta a proporção de jurados suscetíveis. Destacamos que, após cerca de 35 semanas, o valor esperado da população de impositores morais aumenta de $20 \%$ para cerca de $33 \%$ quando consideramos 75\% dos juízes neófitos suscetíveis.

Nos dois casos destacados, a isenção do tribunal do júri fica profusamente afetada.

\section{Considerações finais}

Investigar as formas de inclusão, o tempo de atuação, o interesse dos juízes leigos nos tribunais do júri, bem como os intervalos de não participação nesses tribunais, a fim de avaliar não só o cumprimento da legislação, mas também a experiência, a proximidade e a influência social/legal dos mesmos, foi o caminho encontrado para compreender como aquele espaço interacional pode ser marcado por influências que modelam tanto os vocabulários morais utilizados quanto o próprio sentido do "fazer justiça”, que parece oscilar entre a escolha não esclarecida, ou mesmo cega, e aquela que sustenta certa razão jurídica e técnica.

A defesa do tribunal do júri por parte dos operadores jurídicos que reiteram a "participação democrática do povo" é a mesma que se satisfaz com julgamentos marcados pela fragilidade das provas (ZAMBONI; OLIVEIRA, 2015), reproduzindo a sujeição criminal de certos “tipos sociais” (MISSE, 2010).

A propagação de vícios ou imitações (TARDE, 2000), encontrada tanto nas entrevistas quanto no modelo da sociologia matemática, demonstrou que a inobservância da rotatividade no alistamento pode comprometer sobremanei- 
ra a isenção do julgamento. Mata-se sem anunciar o que há de mais caro na ideia de justiça do tribunal do júri, qual seja, a possibilidade de qualquer cidadão efetivamente julgar, segundo os princípios de sua própria consciência.

Finalmente, esperamos que este trabalho possa ser tomado como uma pequena provocação e convite à reflexão da produção da sentença nos tribunais do júri e que a vida dos que se encontram no banco dos réus não dependa apenas de elementos imponderáveis de sorte ou azar, como observado na introdução deste trabalho.

Agradecimentos: Agradecemos aos revisores pela cuidadosa leitura e valorosos comentários, críticas e sugestões, que permitiram avançar no desafio de repensar o funcionamento dos tribunais do júri, combinando métodos qualitativos, já bastante difundidos nas Ciências Sociais, com um modelo da Sociologia Matemática, pouco utilizado no Brasil. Também agradecemos ao GRAV (Grupo de Relações Afetivas e Violência), em especial à Helma Janielle Souza de Oliveira (doutoranda do PPGS/UFPB) e às ex-bolsistas PIBIC, Emylli Tavares do Nascimento e Laura Nunes Patrício, pela dedicação à pesquisa. Finalmente, agradecemos ao MCTI/CNPQ/MEC/CAPES, pelo auxílio financeiro através do Projeto Noções de justiça nos casos de homicídio afetivo-conjugal: o que dizem os juízes leigos? (2014-2017).

\section{Referências}

ADORNO, Sérgio. (1994), “Crime, justiça penal e desigualdade jurídica: as mortes que se contam no tribunal do júri”. Revista USP, Dossiê Judiciário, n. 21, pp. 132-151.

BARABÁSI, Albert-Laszlo. (2002), Linked: The New Science of Networks. 1. ed. Nova York: Basic Books.

BATITUCCI, Eduardo Cerqueira; CRUZ, Marcus Vinicius Gonçalves da. (2006), "Fluxo do crime de homicídio no Sistema de Justiça Criminal de Minas Gerais". In: XXX ENCONTRO DA ASSOCIAÇÃO NACIONAL DE PÓS-GRADUAÇÃO E PESQUISA EM CIÊNCIAS SOCIAIS, 2006, Caxambu (Minas Gerais). Anais... pp. 15-27.

BECKER, Howard S. (2008), Outsiders: estudos de sociologia do desvio. 1. ed. Rio de Janeiro: Zahar.

BLAY, Eva Alternman. (2008), Assassinato de mulheres e direitos humanos. 1. ed. São Paulo: Ed. 34. 
BOLTANSKI, Luc. (2000), El amor y la justicia como competencias: tres ensayos de sociología de la acción. 1. ed. Buenos Aires: Amorrortu.

BRASIL. Código de Processo Penal (1941), Decreto lei n ${ }^{\circ} 3.689$, de 03 de outubro de 1941. Disponível em: http://www.planalto.gov.br/CCIVIL/Decreto-Lei/Del3689.htm. Acesso em: 05/03/2016, às 15:05:00.

CASTELLS, Manuel. (1999), A Era da Informação: economia, sociedade e cultura, vol. 3. 1. ed. São Paulo: Paz e terra.

COLEMAN, James Samuel. (1964), An introduction to mathematical sociology. 1. ed. London: The Free Press of Glencoe Collie-Macmillan Limited.

CORRÊA, Mariza. (1983), Morte em família. 1. ed. Rio de Janeiro: Graal.

DALEY, Daryl; GANI, Joseph. (2005), Epidemic Modelling: An Introduction. 2. ed. Cambridge: Cambridge University Press.

DEBERT, Guita Grin; LIMA, Renato Sérgio de; FERREIRA, Maria Patrícia Corrêa. (2008), "O Tribunal do Júri e as relações de afeto e solidariedade”. In: DEBERT, Guita Grin; GREGORI, Maria Filomena; OLIVEIRA, Marcella Beraldo de (org.). Gênero, família e gerações: Juizado Especial Criminal e Tribunal do Júri. Campinas: Núcleo de Estudos de Gênero - Pagu/UNICAMP. pp. 111-142.

FACHINETTO, Rochele Fellini. (2012), Quando eles as matam e quando elas matam os matam: uma análise dos julgamentos de homicídio pelo Tribunal do Júri. Tese de Doutorado. Universidade Federal do Rio Grande do Sul Porto Alegre.

FAUSTO, Boris. (2001), Crime e cotidiano: a criminalidade em São Paulo (1880-1924). 1 ed. São Paulo: EDUSP.

GOFFMAN, Erving. (2011), Ritual de interação: ensaios sobre o comportamento face a face. 2. ed. Rio de Janeiro: Vozes.

IZUMINO, Wania Pasinato. (1998), Justiça e violência contra a mulher: o papel do sistema judiciário na solução dos conflitos de gênero. 1. ed. São Paulo: Annablume.

JUNQUEIRA, Eliane Botelho. (1996), "Acesso à Justiça: Um olhar retrospectivo”. Revista Estudos Históricos, n. 18, pp. 389-402.

KERMACK, William Ogilvy; McKENDRICK, Anderson Gray. (1927), "A Contribution to the Mathematical Theory of Epidemics". Proceedings of the Royal Society of London. Section A. Mathematics, n. 115, pp. 700-721.

LIMA, Roberto Kant de. (1999), "Polícia, justiça e sociedade no Brasil: uma abordagem comparativa dos modelos de administração de conflitos no espaço público”. Revista Brasileira de Sociologia e Política, n. 13, pp. 23-38. 
LOREA, Roberto Arriada. (2003), Os jurados "leigos": uma antropologia do tribunal do júri. Dissertação de Mestrado. Universidade Federal do Rio Grande do Sul - Porto Alegre.

MISSE, Michel; VARGAS, Joana Domingues. (2007), “O fluxo do processo de incriminação no Rio de Janeiro na década de 50 e no período 1998-2002”. In: XIII CONGRESSO BRASILEIRO DE SOCIOLOGIA: DESIGUALDADE, DIFERENÇA E RECONHECIMENTO, 2007, Recife. Anais... pp. 1-17.

MISSE, Michel. (2010), “Crime, sujeito e sujeição criminal: aspectos de uma contribuição analítica sobre a categoria 'bandido””. Lua Nova, n. 79, pp. 1538.

NUCCI, Guilherme de Souza. (2014), Tribunal do Júri. 5. ed. Rio de Janeiro: Forense.

PATTEN, Scott; ARBOLEDA-FLOREZ, Julio. (2004), "Epidemic theory and group violence”. Social Psychiatry and Psychiatric Epidemiology, n. 39, pp. 853-856.

PHARO, Patrick. (2015), "Sociologia moral das dependências motivadas: o caso da dependência amorosa”. Sociologias, ano 17, n. 39, pp. 198-223.

RATTON, José Luiz; CIRENO, Flavio. (2007), Violência endêmica: relatório de pesquisa: homicídios na cidade do Recife: dinâmica e fluxo no sistema de justiça criminal. Revista do Ministério Público de Pernambuco - Procuradoria Geral de Justiça, vol. 1, n.1.

RIBEIRO, Ludmila Mendonça Lopes. (2009), Administração da Justiça Criminal na cidade do Rio de Janeiro: Uma análise dos casos de homicídio. Tese de Doutorado. Instituto Universitário de Pesquisas do Rio de Janeiro (IUPERJ) - Rio de Janeiro.

SADEK, Maria Tereza. (2001), Acesso à Justiça. 1. ed. São Paulo: Fundação Konrad Adenauer.

SAMPSON, Robert; RAUDENBUSH, Stephen; EARLS, Felton. (1997), Neighborhoods and violent crime: a multilevel study of collective efficacy. Science, v. 277, Issue 5328, pp. 918-924.

SESTINI, Maria Alice Travaglia. (1979), O tribunal do júri: uma forma de distribuição da justiça. Dissertação de Mestrado. Universidade Estadual de Campinas - Campinas.

SCHRITZMEYER, Ana Lúcia Pastore. (2007), "Afetos em jogo nos tribunais do júri”. São Paulo em Perspectiva, v. 21, n. 2, pp. 70-79.

SCHRITZMEYER, Ana Lúcia Pastore. (2012), Jogo, ritual e teatro: um estudo antropológico dos Tribunais do Júri. 1. ed. São Paulo: Editora Terceiro Nome.

TARDE, Gabriel. (2000), As leis da imitação. 2. ed. Porto: Rés Editora. 
VANDENBERGHE, Frédéric. (2015), "A Sociologia como uma Filosofia Prática e Moral (e vice-versa)”. Sociologias, ano 17, n. 39, pp. 60-109.

WERNECK, Alexandre. (2013), "Sociologia da moral como sociologia da agência”, RBSE - Revista Brasileira de Sociologia da Emoção, v. 12, n. 36, pp. 704-719.

WILSON, Thomas P. (1999), "Sociologia e método matemático”. In: GIDDENS, Anthony; TURNER, Jonathan. (org.). Teoria Social Hoje. 1. ed. São Paulo:UNESP.

ZAMBONI, Marcela; OLIVEIRA, Helma J. S. de. (2015), "Dos que fazem justiça: a percepção dos operadores jurídicos em casos de homicídio afetivo-conjugal”. RBSE - Revista Brasileira de Sociologia da Emoção, v. 14, n. 42, pp. 43-53.

ZAMBONI, Marcela; OLIVEIRA, Helma J. S. de. (2016), Homicídio afetivo-conjugal sob a lente dos operadores jurídicos. 1. ed. João Pessoa: Editora Universitária - UFPB. 